\title{
CHANGING OF VEGETATION ON GREEN ROOF
}

\section{Zuzana Poórová1, Zuzana Vranayová}

${ }^{1}$ Technical University of Košice, Faculty of Civil Engineering, Vysokoškolská 4, Košce 04200, zuzana.poorova@tuke.sk,Slovakia

${ }^{2}$ Technical University of Košice, Faculty of Civil Engineering, Vysokoškolská 4, Košce 04200, zuzana.vranayove@tuke.sk, Slovakia

\begin{abstract}
There is something very idealistic about the odea of putting a garden on your roof. This article is about putting a green roof on even something more funnier, the dog house. The act of greenering part of nature in past, building in present is very popular these days. The idea of this article is to show the change of vegetation used on green roof of the doghouse. The article also presents weathes conditions during theperiod of the observation.
\end{abstract}

Keywords: change in time, different sedum type, green roof

\section{Introduction}

The truth is that for most of us, all this may seem very idealistic. To put a garden on our garage. Why not. But this is where it should start. Lots of joy, beautiful gardens, small domestic green roofs or sheds, garden offices, studios, bicycle sheds and other small structures. This article is about installing, constructing and planting a green roof on a little doghouse (Fig. 1), an opportunity to bring nature back to a place where it has been.

\section{Materials and Methods}

\section{Installed vegetation}

Sempervivum Jovibarba allionii (left), Sempervivum Tectorum (middle) and Sedum Spurium (right) (Fig. 2) were used because of two main reasons. Economical reason: all used plants were taken directly from nature, meaning cheap version of having plants for free. Low/ no maintenance reason: used plants need low/ no maintenance and no irrigation.

\section{Hardy succulents and their qualities}

These types of flowers are the workhorses of extensive roofs and the primary plants for systems using a medium of 10 , or less centimeters. They have unsurpassed ability to survive drought and wind conditions, store water in their leaves for extended periods and conserve water through a unique metabolic process. Hardly succulents like Sempervivum Jovibarba allionii, Sempervivum tectorum and Sedum spurium are one of the choices for thin substrate, non-irrigated, extensive green gardens with the greatest survivability [2].

\section{Plant establishment on the green roof}

Planting is the key to green roof's longevity. If the establishment in the beginning is unsuccessful, time of the return of investments is going to be lengthened. It is very important and also much cheaper to ensure the plant establishment in the beginning 
or even before the realization of the roof. First weeks after installation are crucial. It is prudent to plant the plants early enough to allow plants to root in before the first frost. Trials performed at Penn State University on plant establishment showed that wellestablished plants were much more likely to survive winter and drought than plants that were poorly established [3].

Plant establishment on the doghouse roof was ensured before the roof realization. Three types of used vegetation, Sempervivum Jovibarba allionii, Sempervivum tectorum and Sedum spurium, were prepared for being planted on the roof. One half of Sempervivum Jovibarba allionii and Sempervivum tectorum was planted in containers one week before planting plants on the roof of the doghouse. After moving these plants out of the container (one week period), new established root system of these plants was noticed. Another half of Sempervivum Jovibarba allionii and Sempervivum tectorum was planted on the roof directly after removing plants out of the soil they were growing in. Sedum spurium was planted on the roof directly after removing plants out of the soil they were growing in. The roof is exposed to the west, because of the plant choice.

After plant establishment, few minutes after finishing planting vegetation heavy rain came. To ensure that rain would not wash out the soil and freshly planted vegetation, roof was covered with plastic foil. When the rain was soft, plastic foil was removed and the roof was naturally watered with rainwater.

\section{Experiment}

Another fact about any green roof is that it is always an experiment. No one can predict if the plant establishment will be successful or not. In this case, awkward situation happened after few days when missing plants were noticed. Seven Sempervivum Jovibarba Allionii plants from the very bottom part of the roof were missing. Two were found on the ground and the dog was caught while playing and jumping up, trying to tear out another one.

\section{Medium depth}

The depth of medium used on the doghouse roof is constant $6 \mathrm{~cm}$. This was effected by two main reasons. Plant specification reason: used plants do not require deeper substrate depth. Construction reason: the doghouse was designed as a simple construction to support low load of soil. Before plants were installed, all engineer and protective works on the roof were completed to ensure avoiding potential damage to the plants. When the roof was ready for the planting, the medium was spread to the specific depth and thoroughly moistened. Plastic film was not be laid over the substrate, because it could have caused overheating the medium and affect planted plants later.

\section{Medium type}

Type of medium used on the doghouse is purely organic with no artificial materials. Soil composition was designed for mostly economical reasons. In future, this green roof may be compared with another green roof with different roof layers. Medium is surrounded with layer of gravel. This layer is designed for winter season when soil expansion is possible. Gravel border is also making the roof look more fashionable and well designed. 


\section{Construction}

The doghouse disposition: vestibule and the dog's room. The construction consists of floor, five walls and the roof. Entry to the dog's room is inside the doghouse from the vestibule, under the roof. The roof is aisle with $22^{\circ}$ slope. Floor dimension is $800 \times 800$ $\mathrm{mm}$. Roof dimension is $1000 \times 1000 \mathrm{~mm}$. The roof is overhanging $100 \mathrm{~mm}$ the floor on each side. Height of the wall with the entrance is $450 \mathrm{~mm}$, opposite wall height is 750 $\mathrm{mm}$. Signature element of this roof is horizontal division into three parts. The division has aesthetical reasons but main reason of avoiding soil slide. There are holes in the construction bottom parts dividing the roof into three parts. These holes are ensuring water runoff during storm rainfall. Construction of the doghouse is made of $15 \mathrm{~mm}$ thick OSB boards. The dog's room is insulated with thermal insulation. Construction of the roof is described in Tab. 1. Change of vegetation between January 2016 and August 2016 can be seen on Figures 3-6.

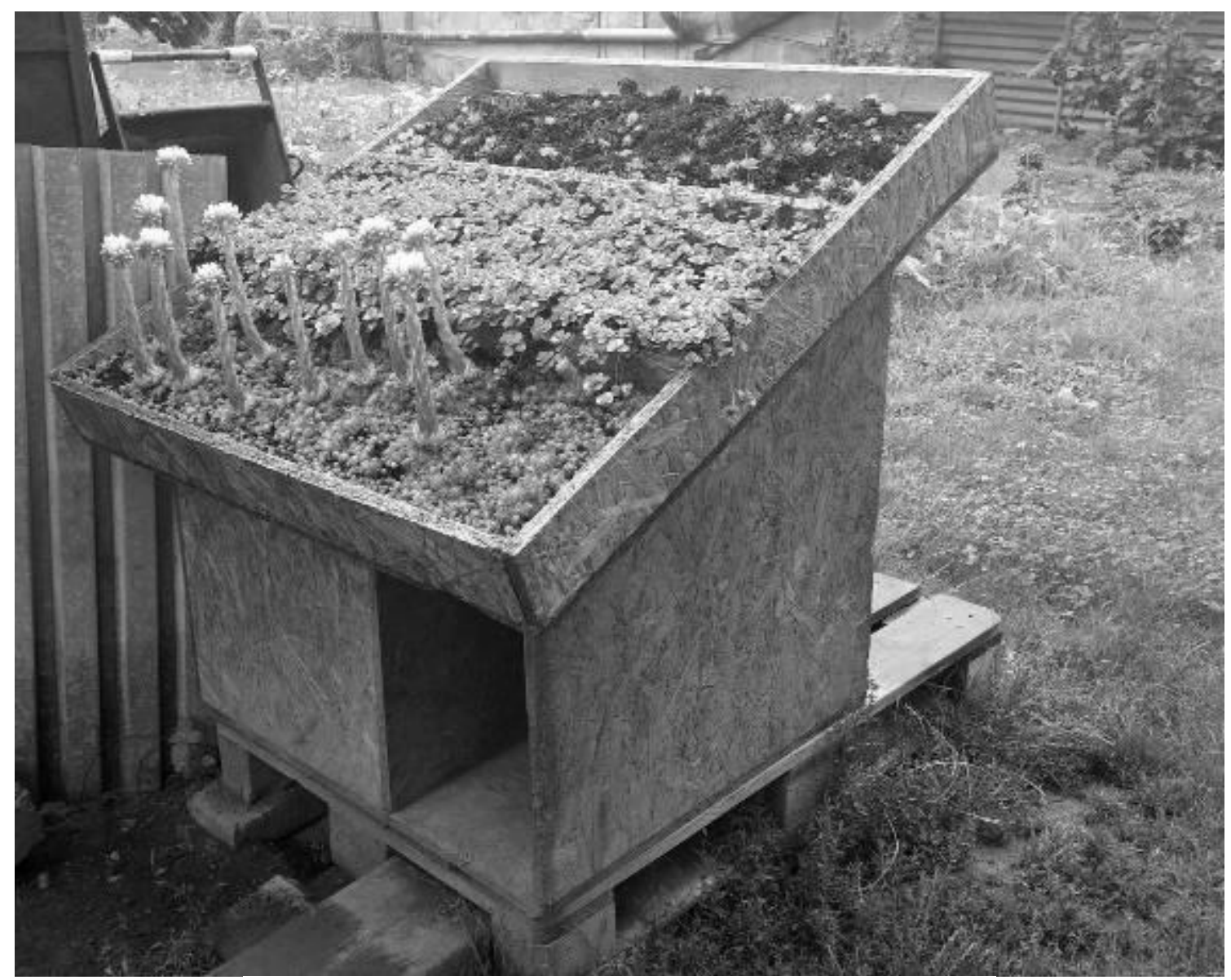

Figure 1: Doghouse and its green roof (source: author)

Table1: Construction of the roof

\begin{tabular}{c|c}
\hline vegetation & - \\
\hline soil & $60 \mathrm{~mm}$ \\
\hline $300 \mathrm{~g}$ filter fabric & $1,5 \mathrm{~mm}$ \\
\hline water holding drainage layer & $10 \mathrm{~mm}$ \\
\hline waterproof membrane & $0,1 \mathrm{~mm}$ \\
\hline
\end{tabular}


INCD ECOIND - INTERNATIONAL SYMPOSIUM - SIMI 2016

"THE ENVIRONMENT AND THE INDUSTRY", PROCEEDINGS BOOK

\begin{tabular}{c|c}
\hline waterproof coating & 2 coats of paint \\
\hline osb board & $15 \mathrm{~mm}$ \\
\hline
\end{tabular}

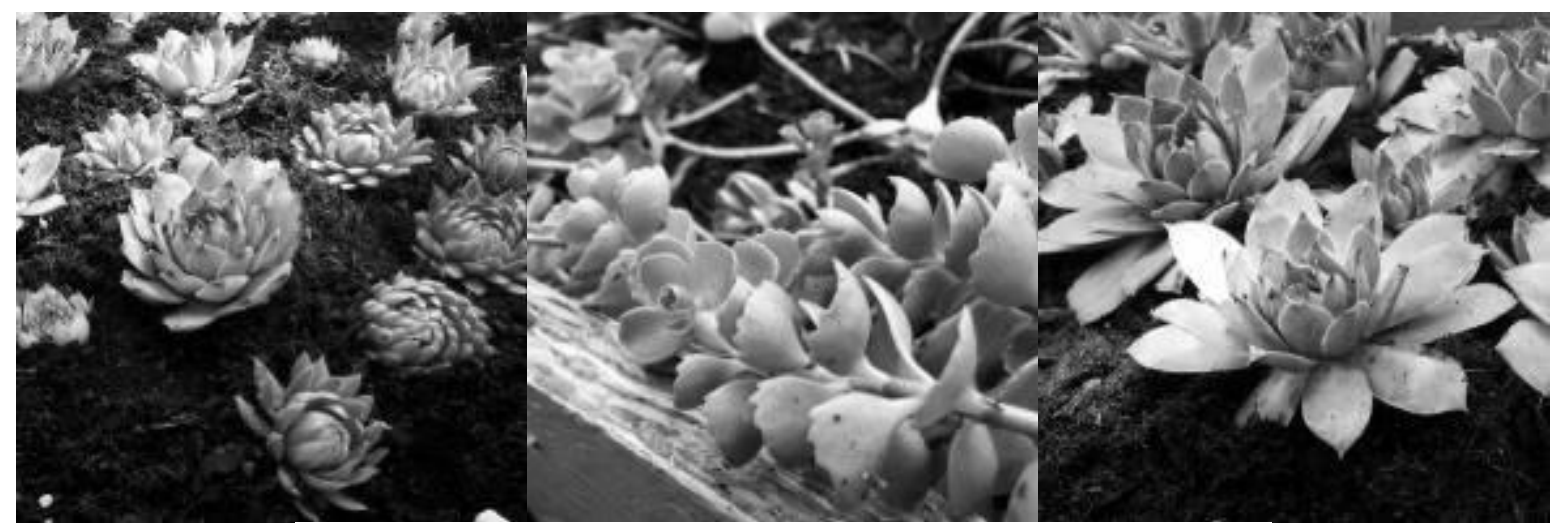

Figure 2: Sedums used on the green roof (source: author)


Figure 3: Doghouse in 01/2016, 02/2016 (source: author)

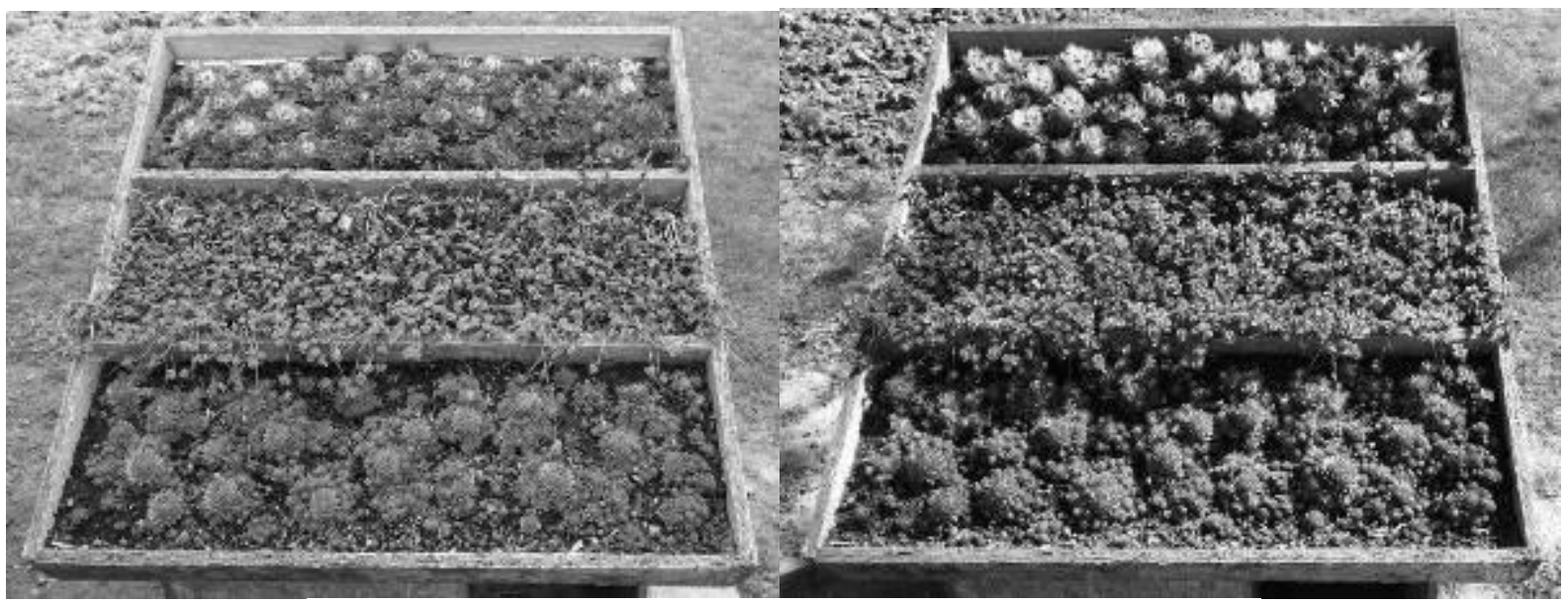

Figure 4: Doghouse in 03/2016, 04/2016 (source: author) 


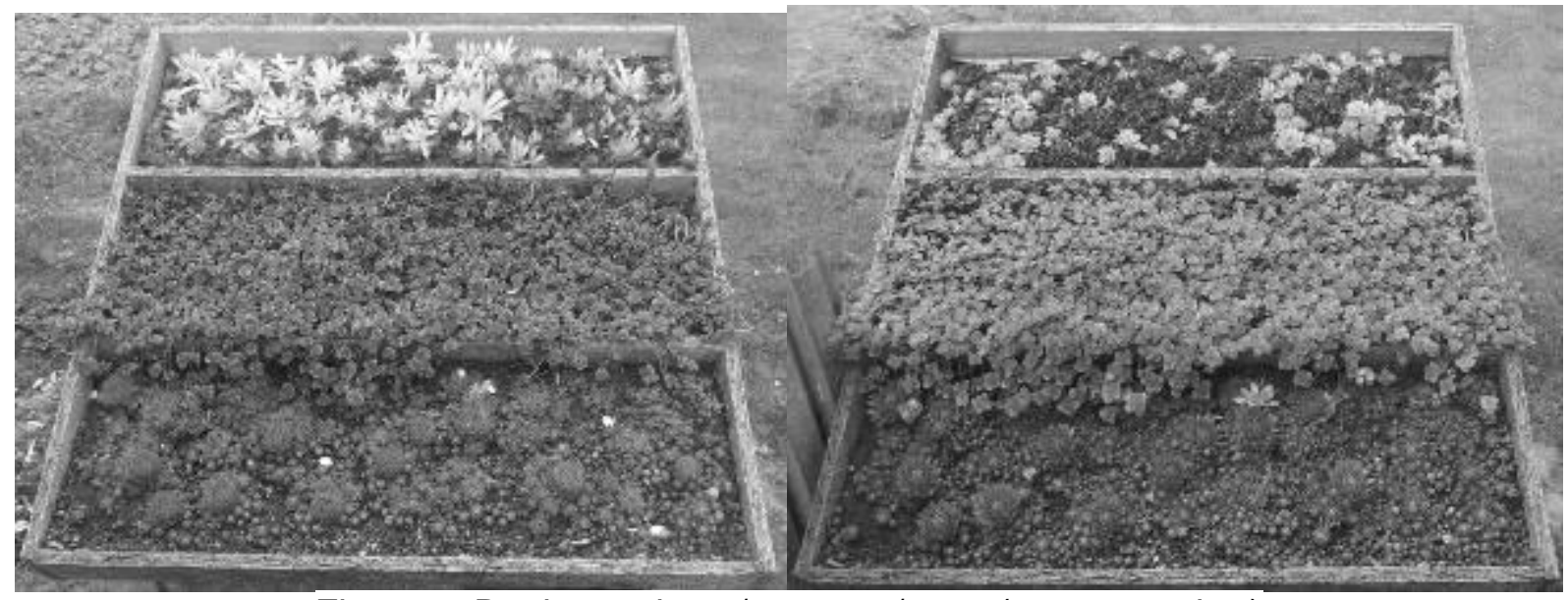

Figure 5: Doghouse in 05/2016, 06/2016 (source: author)
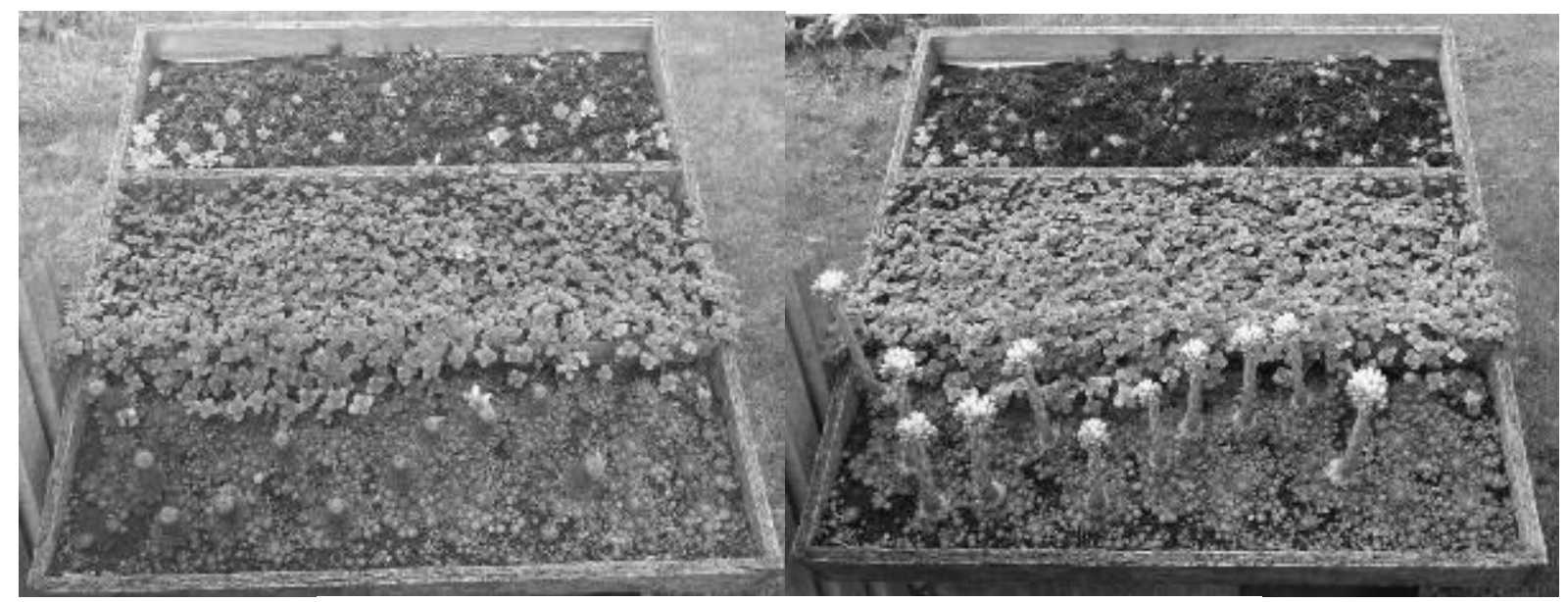

Figure 6: Doghouse in 07/2016, 08/2016 (source: author)

\section{Results and Discussion}

Weather was observed between January 2016 and August 2016 . Every month in approximately 30 days interval. Maximum high temperature $\left({ }^{\circ} \mathrm{C}\right)$ (Fig. 8), minimum low temperature $\left({ }^{\circ} \mathrm{C}\right)$ (Fig. 9), rain precipitation (mm) (Fig. 10), snow precipitation (cm) (Fig. 11 ) and humidity (\%) (Fig. 12) were monitored using www.accuweather.com data. All monitored data can be found in Table 2 and the changes of the data can be seen in Figures 7-11.

Table2: Weather conditions

\begin{tabular}{c|c|c|c|c|c}
\hline date & $\begin{array}{c}\text { max. high day } \\
\text { temperature }\left[{ }^{\circ} \mathrm{C}\right]\end{array}$ & $\begin{array}{c}\text { min. low day } \\
\text { tempertature }\left[{ }^{\circ} \mathrm{C}\right]\end{array}$ & rain $[\mathrm{mm}]$ & $\begin{array}{c}\text { snow } \\
{[\mathrm{mm}]}\end{array}$ & $\begin{array}{c}\text { humidity } \\
{[\%]}\end{array}$ \\
\hline 24.01 .16 & -4 & -6 & 0 & 0,9 & 85 \\
\hline 07.02 .16 & 7 & -1 & 0 & 0 & 68 \\
\hline 14.3 .2016 & 4 & -1 & 2 & 0 & 66 \\
\hline 1.4 .2016 & 17 & 13 & 0 & 0 & 54 \\
\hline 15.5 .2016 & 18 & 9 & 0 & 0 & 57 \\
\hline 15.6 .2016 & 25 & 12 & 0 & 0 & 54 \\
\hline 15.7 .2016 & 30 & 17 & 0 & 0 & 49 \\
\hline 1.8 .2016 & 32 & 18 & 4 & 0 & 54 \\
\hline
\end{tabular}




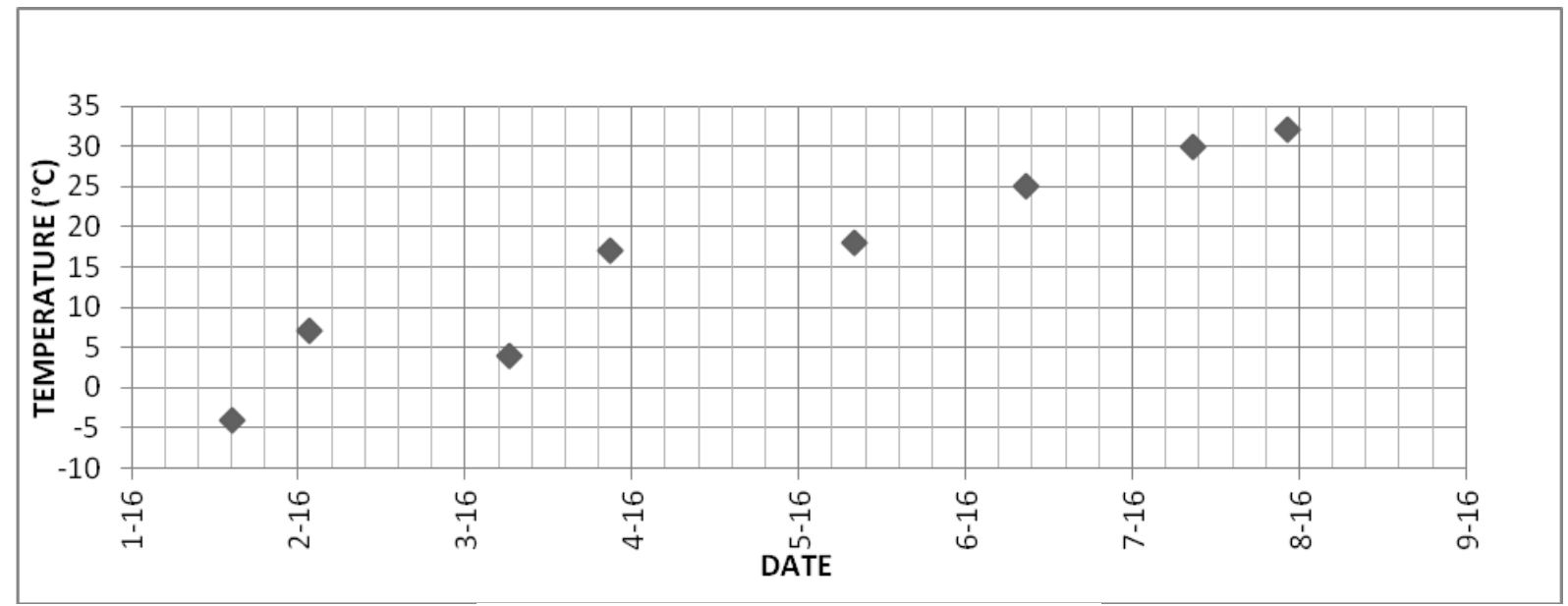

Figure 7: Maximum day temperatures

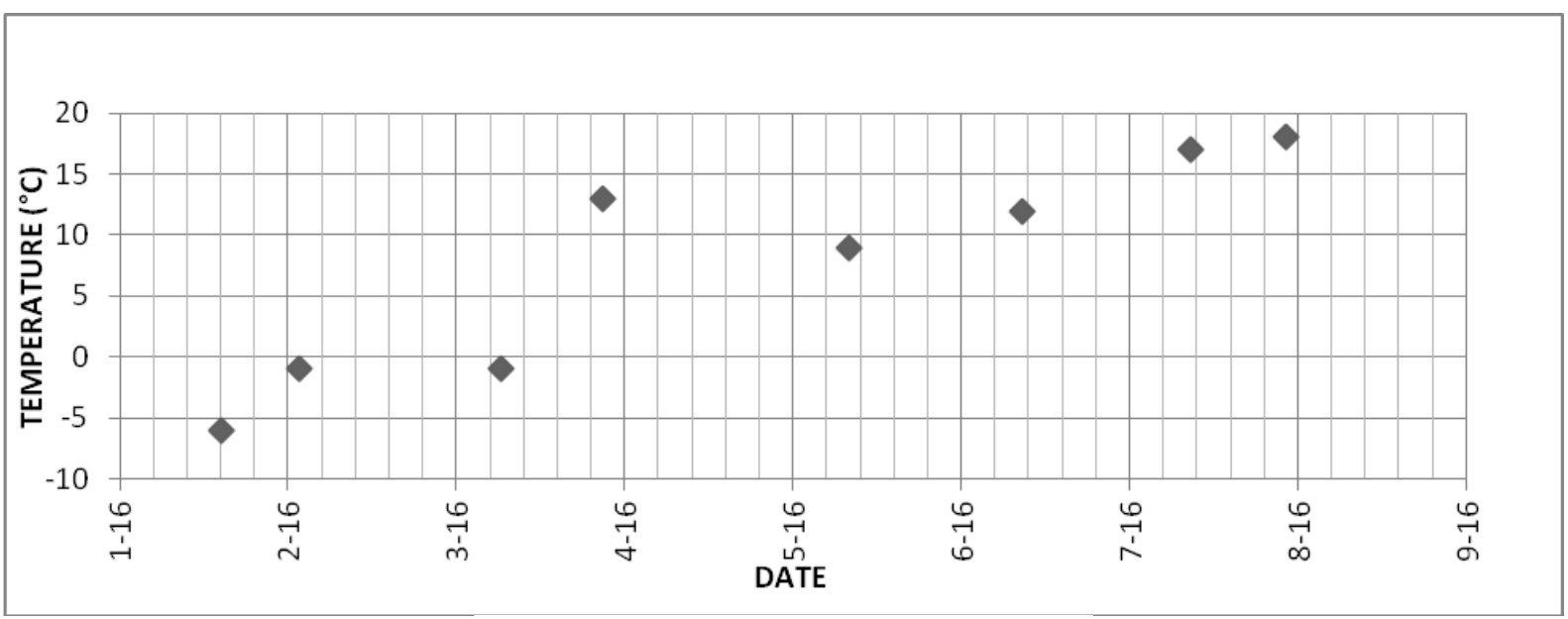

Figure 8: Minimum day temperatures

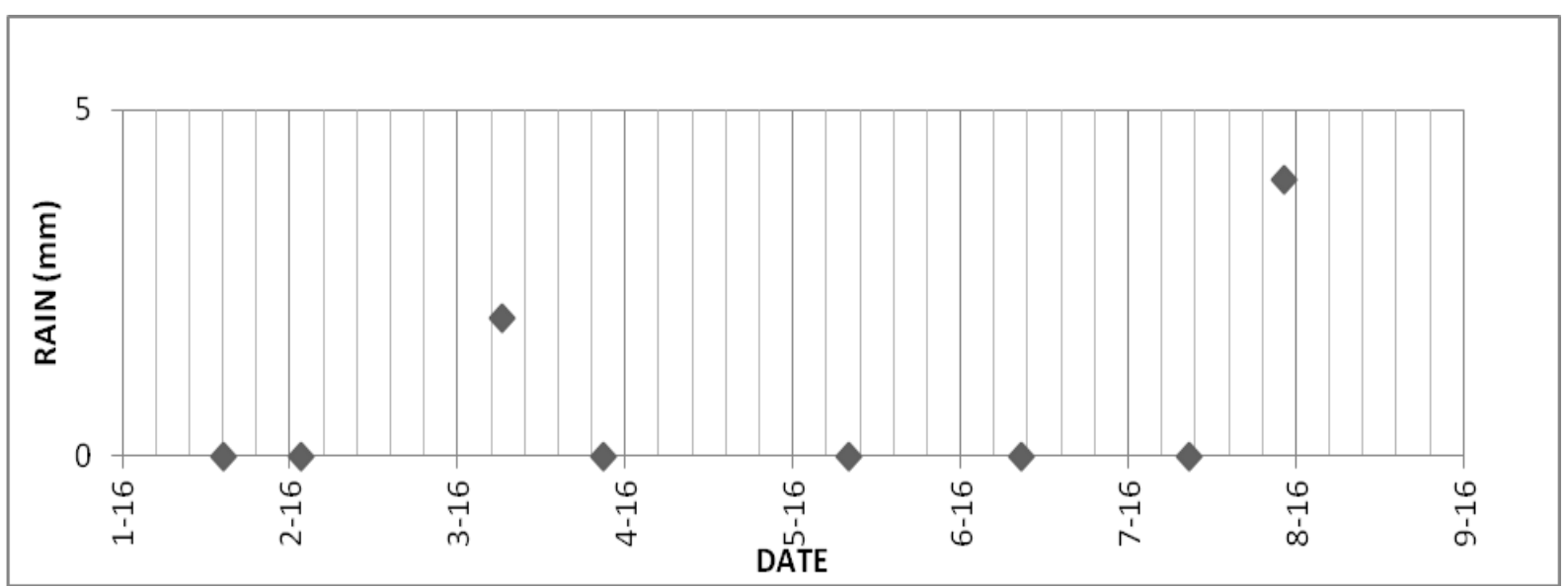

Figure 9: Rain precipitation 


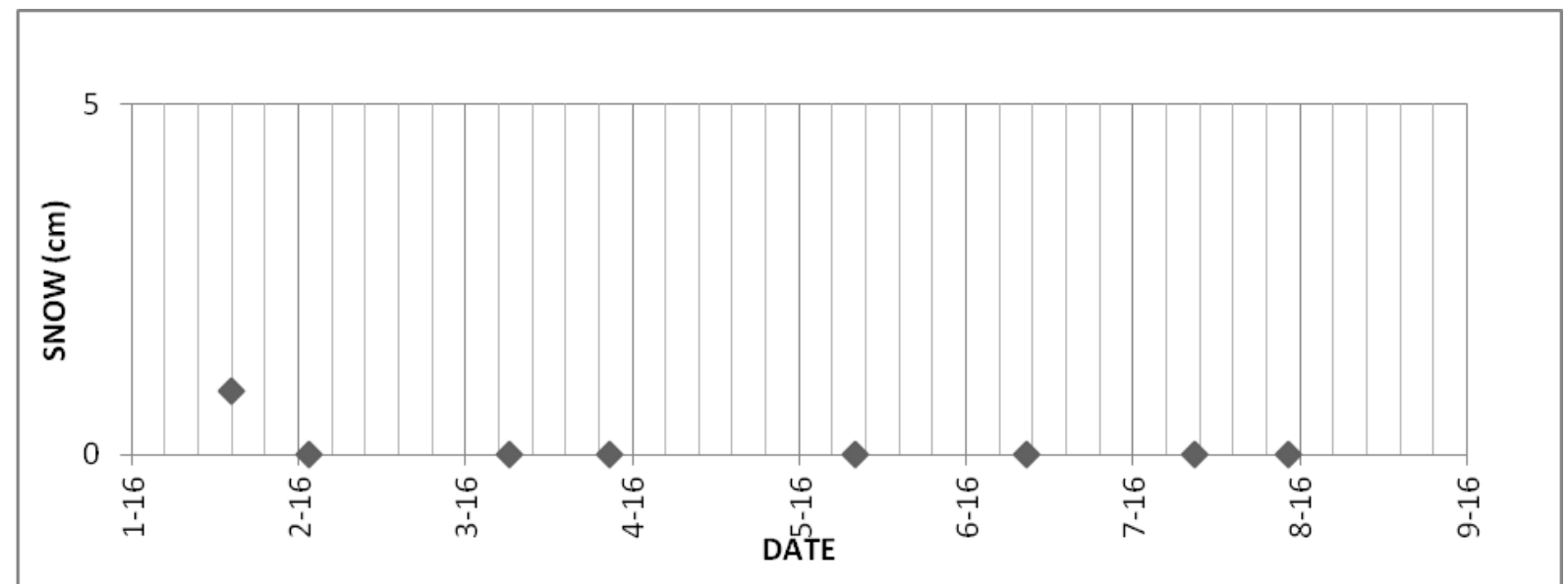

Figure 10: Snow precipitation

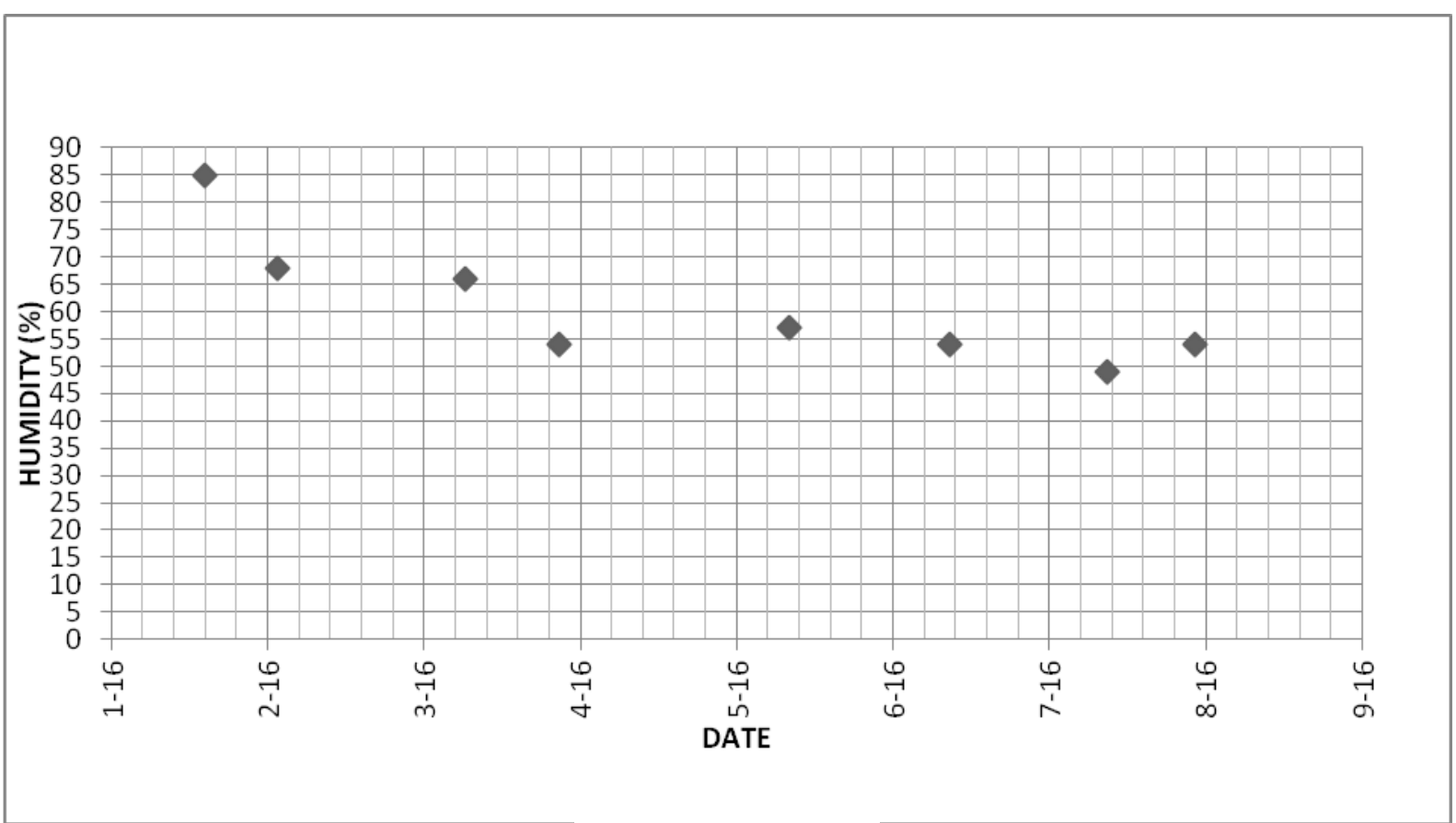

Figure 11: Humidity

\section{Conclusions}

The main idea of this article was to show the change of vegetation in time. Sempervivum Jovibarba allionii showed the biggest change in terms of growing and blooming flowers. Sempervivum Tectorum was changing in February, the leaves started to grow ang get bigger, but there was no significant change. Sedum Spurium was the only sedum type that did not survive this period of time. Few flowers of this type remained in sedum, the research will continue and the green roof will be observed.

\section{Acknowledgements}

This work was supported by: VEGA 1/0202/15 Bezpečné a udržatel'né hospodárenie $\mathrm{s}$ vodou v budovách tretieho milénia/ Sustainable and Safe Water Management in Buildings of the 3rd. Millennium. 


\section{References}

[1] Dunnett N. et al., 2011. Small green roofs, Timber press, PortlandLodon, p.8-13

[2] Snodgrass, E. C., Green roof plants. Timber press, PortlandLondon, 2006

[3] Thuring, C. E., Green roof plant response to different media depth under various drought conditions. http://horttech.ashspublications.org/content/20/2/395.full (17-052015) 